\title{
La metáfora del castillo en la poesía de Jorge Manrique según la arquetipología de Durand
}

\author{
Javier Roberto GoNZÁLEZ \\ Universidad Católica Argentina / CONICET \\ (Facultad de Filosofia y Letras / Centro de Estudios de Literatura Comparada) \\ Academia Argentina de Letras \\ javier_gonzalez@uca.edu.ar
}

\section{LA METÁFORA DEL CASTILLO}

La metáfora del castillo asaltado y su desarrollo narrativo alegórico constituyen un tópico en la poesía de los cancioneros castellanos como expresión de la conquista amorosa. Así, el castillo como construcción arquitectónica sólida y bien pertrechada suele representar el cuerpo del enamorado, tomado por asalto por las huestes atacantes del amor -la belleza ante todo- y vencido al cabo por estas, pese a la fortaleza de su defensa y a la protección de sus sentidos y facultades racionales. En ocasiones, los roles se invierten y el castillo conquistado -o vanamente asaltado- pasa a simbolizar a la dama, y el atacante al caballero (Domínguez 1988: 34-36). Se trata en ambos casos de plasmaciones parciales de la más amplia alegoría feudal-vasallática que entiende al amor en términos de guerra y a los amantes como contendientes o batalladores. Jorge Manrique emplea con frecuencia la metáfora del castillo en el contexto de la imaginería erótico-bélica de su lírica cortesana (Battesti-Pélégrin 1984: 7-31; Domínguez 1988: 31-40; Casas Rigall 1995: passim; Compagno 2008: 121-135, Piña Pérez 2020: 83-98), y también recurre a ella, en un contexto harto diverso y con muy otros propósitos, en una celebrada imagen de sus Coplas a la muerte de su padre (xxiv, 277-288) (Gilman 1991: 277-302; Zepeda 2006: 33-43). Se trata a todas luces de un tópico de la retórica cancioneril, pero como bien señaló Dámaso Alonso (1958) en su clásico trabajo sobre Berceo, «el uso de los tópicos tradicionales convive perfectamente con la expresión individual del escritor. La obra literaria es un compromiso entre tradición y expresión individual» (p. 82), y así como Berceo no solo reeditaba mecánicamente un topos cuando hablaba de su urgencia por acabar de escribir ante la proximidad de la noche, sino reflejaba una vivencia personal y real, también don Jorge recurre a los castillos a la hora de metaforizar los asaltos del amor o de la muerte no solo por fidelidad a la tópica vigente, sino 
también como reflejo realista, documental incluso en algunos casos, de su propia vida de guerrero ${ }^{1} \mathrm{y}$ sus experiencias concretas en el arte militar de la poliorcética, esto es, en el ataque y la defensa de plazas fuertes ${ }^{2}$.

Existen ya trabajos, señalados más arriba, que se han ocupado de la metáfora del castillo tomado por asalto en la poesía amatoria de don Jorge -los más de ellos-o bien en las Coplas, pero ninguno ha integrado los análisis que exigen estos dos diferentes contextos, erótico y doctrinal respectivamente, o bien los diferentes actantes alegorizados por el castillo y la fuerza atacante en cada caso -el amor o uno de los enamorados, la vida y la muerte- en un único intento descriptivo e interpretativo de la metáfora estudiada. Será nuestro objetivo en estas páginas acometer tal tarea, procurando: a) determinar para la metáfora del castillo asaltado los rasgos morfológicos y funcionales que resultan comunes a ambos contextos, el erótico y el doctrinal -más allá de aquellos que resulten específicos de cada uno, que serán igualmente señalados y considerados-; b) establecer ciertas constantes de estrategia e imaginario poéticos que confieren unidad e identidad a la personalidad artística de Manrique por encima de cualesquiera moldes retóricos o especies formales particulares.

\section{LA METÁFORA DEL CASTILLO EN LOS POEMAS AMATORIOS}

Comenzaremos por el poema "Con el gran mal que me sobra», que encabeza en el Cancionero General de 1511 la serie de obras de Jorge

\footnotetext{
${ }^{1}$ Va de suyo que entre estas experiencias de su propia vida referidas a asaltos de castillos no podemos contar como plausible fuente directa de su poesía sobre este tópico a la más famosa de todas, ocurrida en torno al castillo de Garci Muñoz en 1479, pues a raíz de este asalto el poeta resultó mortalmente herido por su enemigo Pedro de Baeza, y falleció pocos días después en Santa María del Campo, sin tiempo ni energías suficientes para recoger su reciente vivencia bélica ante el castillo en ningún ejercicio poético al caso. Vid. Serrano de Haro (1966: 348-362).

${ }^{2}$ «A mí me parece que aunque ignoráramos la vida de Jorge Manrique, leyendo su obra tendríamos la certeza de que fue un guerrero de los pies a la cabeza. [...] Rara es la composición de Jorge Manrique donde no aparece la presencia militar. Será la herida en el corazón, la muerte en descampado, la escaramuza resuelta en celada, el recurso a la hermandad, la impresionante revista que en las Coplas pasa a baluartes, ejércitos, banderas sobre los que acecha la destrucción. Hay composiciones muy típicas, "Castillo de Amor", en que la teoría militar se trasmuta íntegramente en simbología amorosa. La descripción del castillo está meticulosamente hecha en guerrero, y si Menéndez y Pelayo leyéndola creía encontrarse literariamente ante la fortaleza de Montizón, la realidad es que en algunos pasajes la descripción poética de D. Jorge coincide casi con la que administrativamente redactaron los visitadores de Santiago al inspeccionar Montizón en 1478. [...] La "Escala de Amor" es un asalto escuetamente descrito, uno de tantos en los que realmente pudo participar. Es muy frecuente en la poesía de la época el símil militar, hasta en trovadores y poetas de los que se desconoce tuvieran actividades bélicas, como Juan de Mena y Villasandino, o Álvarez Gato. Pero encuentro que el uso en D. Jorge de términos y metáforas de esta índole es más determinante que en la mayoría de los poetas de su tiempo. [...] En Jorge Manrique parece primar la experiencia castrense. Acude a ella para expresarse como a su elemento verdaderamente familiar. Emplea los términos sin resonancias, con preciso sentido ambivalente, bélico o erótico» (Serrano de Haro 1966: 124-125).
} 
Manrique a modo -así lo han entendido Beltrán (2013: 3) y Morrás (2003: 100)- de texto proemial o programático, pues viene a sintetizar en modo perfecto la poética del amor cortés que identifica a los textos que le siguen. El poema describe el proceso completo de enamoramiento según los cánones corteses, recurriendo a sus más frecuentes tópicos: el amor como padecimiento y lamento y su intrínseca inefabilidad (estr. 1 y 2), el enamoramiento de oídas o amor de lonh y la inmediata pérdida de libertad del amante (estr. 3), el proceso de conquista amorosa considerado metafóricamente como el arduo asedio de una plaza militar, que es lo que principalmente nos interesa aquí (estr. 4 a 7), la centralidad de la mirada como canal eminente del intercambio de sentimientos y la mutación de la inicial dicha de amor en desdicha ante el rechazo de la dama (estr. 8 y 9), la vivencia de este rechazo como un cabal martirio seguido de una muerte sacrificial de amor, según el modelo hiperbólico del martirologio religioso (estr. 10 a 12). En consonancia con el patetismo y la exageración que resultan propios de la perspectiva adoptada, la retórica del poema se funda en la recurrencia de paradojas, antítesis, paralelismos, rimas internas y figuras etimológicas, recursos propios de la estética conceptista de la lírica amatoria cancioneril. Reparemos en las cuatro estrofas donde se desarrolla la metáfora del castillo asediado:

\section{Emprendí, pues, noramala, ya de veros por mi mal, y en subiendo por la escala, no sé cuál pie me resvala, no curé de la señal. Y en llegando a la presencia de bienes tan remontados, mis desseos y cuidados todos se vieron lançados delante vuestra excelencia.}

Allí fue la gran cuistión entre querer y temor, cada cual con su razón esforçando la passión y alterando la color. $\mathrm{Y}$ aunque estava apercebido y artero de escarmentado, cuando ovieron concluido, el temeroso partido se rindió al esforçado.

Y como tardé en me dar esperando toda afruenta, después no pude sacar 


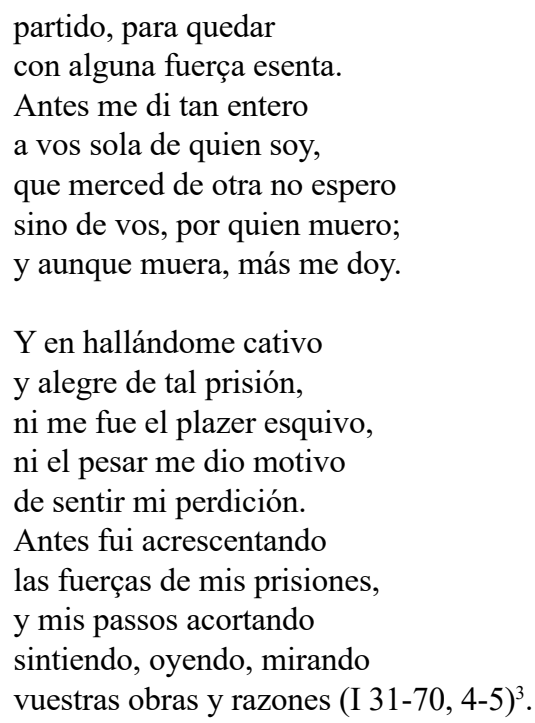

Resulta notable que el castillo no esté en absoluto descrito, sino apenas aludido mediante el gesto de escalar su torre; es, con todo, una alusión tan clara, que a partir de ese único dato kinésico resulta factible la identificación de la entera situación del asedio de la plaza fuerte, de su toma y del irónico desenlace de quedar el amante conquistador cabalmente vencido por la amada conquistada. Se trata de una de las tópicas paradojas corteses de este tipo de poesía, en la cual el atacante escalador, identificado como el agente del sentimiento amoroso y la parte masculina y activa del proceso erótico, deviene al cabo de su «exitosa» operación militar un pasivo y paciente cautivo de aquella contraparte femenina, la amada asediada en el castillo, que ha pasado a dominar a su conquistador mediante las simbólicas cadenas de su propio ámbito, convertido así en cárcel de amor ${ }^{4}$. La paradoja se expresa imaginalmente en términos de espacialidad: el amante ejerce su condición activa mediante su gesto de trepar a la torre con una escala, esto es, de superar o vencer

${ }^{3}$ Todas nuestras citas de Manrique remiten a la edición de 2013 de Vicenç Beltrán. Se indican número de poema, versos y páginas.

${ }^{4}$ Este desenlace con peripecia irónica, según la cual el conquistador resulta conquistado y la vencida vencedora, se corresponde muy bien con el juicio de Battesti-Pélégrin acerca de la poesía de los cancioneros en general y de don Jorge en particular: «Dans le langage courant, comme dans la littérature chevaleresque, aucune équivoque n'est d'ordinaire possible sur le sens et l'issue du combat amoureux. Dans la stratégie de la guerre en amour, le siège (de la femme) débouche sur l'inévitable victoire du héros. La poésie cancioneril que Jorge Manrique illustre parfaitement en cela, consacre au contraire l'indiscutable et irrémédiable défaite d'un amant qui, depuis toujours, avant même que de combattre, s'avoue vaincu. Voici donc inversée, et dévoyée de son sens chevaleresque, la stratégie guerrière de la seduction. Et d'abord parce que la situation change: d'attaquant, d'assiégeant, le poète dévient l'assiégé» (BattestiPélégrin 1984: 18-19). 
la altura que lo separa de su objetivo ${ }^{5}$, pero resulta después vencido y aprisionado en y por el interior del castillo escalado, que deviene cárcel, y por quien mora en dicho interior, la amada, que deviene así la verdadera triunfadora de la guerra. El triunfo del caballero se ha limitado entonces a la breve etapa inicial del asalto, y se revela como transitorio: el escalador logra subir, pues accede finalmente a la presencia de la dama -y en llegando a la presencia / de bienes tan remontados-, pero no sin tropiezos, pues su pie resvala, lo cual viene adjudicado a no haber prestado atención a la señal, evidente dilogía que alude, por una parte, al campo semántico de la heráldica presente en toda acción militar, pero también a posibles malos presagios o augurios que le advirtieron del infortunio sin ser atendidos. El triunfo de la dama, por el contrario, es el triunfo final y definitivo de la guerra, por rendición del caballero $-s e$ rindió al esforçado-. Se identifican entonces como correlatos opuestos las series sucesivas $[$ ascensionalidad $=$ actividad $=$ triunfo transitorio de lo masculino] vs. [interioridad $=$ pasividad $=$ triunfo definitivo de lo femenino]. Se trata de una doble violencia, de una acción bélica de asalto seguida de una reacción vindicativa de cárcel y cadenas, que se inscribe en el particular gusto de Manrique por la manifestación directa de pulsiones de ira, fuerza, enfrentamiento, crispación, crueldad ${ }^{6}$. La inicial y engañosa victoria masculina se expresa en el movimiento, la final y verdadera victoria femenina en la quietud; la primera resulta efímera, la segunda permanente.

Pero lo más importante en el análisis de estas dos mociones bélicoeróticas sucesivas, a los efectos de la imaginación poética, es que la actividad y la transitoriedad masculinas hallan su cauce en lo que Gilbert Durand ha denominado el régimen simbólico diurno, en tanto la pasividad y la permanencia femeninas lo hacen según el régimen simbólico

${ }^{5}$ «[...] el Eje del Universo es como una escala por la cual se efectúa un perpetuo movimiento ascendente y descendente. Permitir que tal movimiento se realice es, en efecto, el destino esencial de la escala; y puesto que, según acabamos de ver, el árbol o el mástil desempeña también la misma función, bien puede decirse que en este respecto la escala es su equivalente. [...] Se ve que la escala ofrece, así, un simbolismo muy completo: es, podría decirse, como un "puente" vertical que se eleva a través de todos los mundos y permite recorrer toda su jerarquía, pasando de peldaño en peldaño; $y$, a la vez, los peldaños son los mundos mismos, es decir, los diferentes niveles o grados de la Existencia universal. Esta significación es evidente en el simbolismo bíblico de la escala de Jacob [...]. Por eso, sobre todo cuando la escala se emplea como elemento de ciertos ritos iniciáticos, sus peldaños se consideran expresamente como representación de los diversos cielos, es decir, de los estados superiores del ser» (Guénon 1988: 294-295). Ideas muy similares se hallan en Durand (2004: 132-134).

${ }^{6}$ «Junto a la ideología hay que aludir también a la actitud general de violencia de Jorge Manrique. Sus poemas tienen frecuentemente aire de reto, se enfrentan, y preferentemente con el poderoso, llámese amor o fortuna. En este enfrentamiento con el más fuerte se vislumbran no solo móviles de justicia, sino también un gusto psicológico por la violencia en sí, por el riesgo. [...] En este sentido habría que analizar el vocabulario de D. Jorge que arroja gran cantidad de términos violentos: fuerza, porfía, rabia, amenaza, contienda. Gran parte de su poesía está en función de una hostilidad, de un enemigo, insistentemente crispada» (Serrano de Haro 1966: 126-127). 
nocturno. Durand clasifica los innúmeros símbolos de la tradición universal no a partir de sus formas sino en torno de pocas imágenes básicas de movimiento; considera tres gestos reflejos corporales elementales: el postural -la puesta de pie o conquista de la vertical humana-, el digestivo o deglutivo -la moción alimentaria de succión y engullimiento-, y el rítmico o cíclico -referido tanto a la dinámica del sexo cuanto a los ciclos vitales y estacionales de la fertilidad y el celo-. El primer gesto «exige las materias luminosas, visuales, y las técnicas de separación, de purificación, cuyos frecuentes símbolos son las armas, las flechas, las espadas [y los elementos axiales y ascensionales]» (Durand 2004: 57); el segundo «suscita las materias de la profundidad: el agua o la tierra cavernosa, los utensilios continentes, las copas y los cofres; y se inclina por las ensoñaciones técnicas de la bebida o el alimento» (ibid. 57); por último, los gestos rítmicos, cuyo modelo natural consumado es la sexualidad, «se proyectan sobre los ritmos estacionales y su cortejo astral, anexando todos los sustitutos técnicos del ciclo: la rueda y el torno, la mantequera y el eslabón; y finalmente, sobredeterminan todo frotamiento tecnológico mediante la rítmica sexual» (ibid. 57). De estos tres gestos dominantes surgen dos regímenes simbólicos que Durand llama diurno -correspondiente a los símbolos relacionados con la dominante postural ascendente o verticalizante ${ }^{7}$ - y nocturno -que reúne los símbolos de la gestualidad tanto digestiva como rítmica-; el segundo régimen, empero, necesariamente se subdivide en dominante digestivo-deglutiva y dominante rítmico-cíclica: «[...] la primera subsume las técnicas del continente y el hábitat, los valores alimenticios y digestivos, la sociología matriarcal y nutricia, y la segunda agrupa las técnicas del ciclo, del calendario agrícola y de la industria textil, los símbolos naturales o artificiales del retorno» (Durand 2004: 60-61). Conforme entonces a esta nominal bipartición diurna / nocturna, que entraña una real tripartición diurna / nocturna digestiva / nocturna rítmica, observamos en nuestro poema que Manrique representa la victoria inicial y efímera del caballero mediante una neta simbología diurna, el ascenso verticalizante por la escala, en tanto expresa la final y perdurable victoria de la dama mediante el gesto nocturno y deglutivo de la inhabitación todopoderosa en el interior del castillo, interior que literalmente engulle, y al hacerlo domina y aprisiona, a aquel que venía a conquistarlo. En términos de la arquetipología durandiana, bien podemos afirmar que detrás de la guerra de los amantes se esconde una virtual guerra de regímenes simbólicos, y

${ }^{7}$ Según Durand (2004: 127-184) en el régimen diurno pueden distinguirse tres grupos de símbolos, todos ellos relacionados con el poder benéfico que garantiza victoria y pureza: los ascensionales -que remiten al gesto verticalizante de la axialidad, la sumidad, la elevación-, los espectaculares -que remiten al campo semántico de la luz, la visión, el brillo-, y los diairéticos -que engloban elementos de lucha como las armas materiales cortantes y las armas espirituales de purificación-. 
que en tal guerra el régimen nocturno ha vencido al diurno al imponerse la interioridad sobre la sumidad o verticalidad en esta curiosa compulsa entre los más apropiados o eficaces gestos de conquista y dominio. En cuanto sumidad, en cuanto altura, en su manifestación como torre, el castillo solo resultó vencido en apariencia y en transitoriedad; en cuanto interioridad, en cuanto espacio íntimo y reservado, en su manifestación como cámara, el castillo resultó inexpugnable y pasó de conquistado a conquistador $^{8}$. La cámara cerrada puede más que la torre elevada en la dinámica de la defensa, pero también en la del ataque, pues la cámara no solo ha rechazado y neutralizado el asalto del caballero, sino ha pasado a la ofensiva y lo ha hecho prisionero. El poder se ha transferido de lo masculino-ascensional-diurno a lo femenino-interior-nocturno. Se trata, bien mirado, de un desenlace que con fina intuición el poeta ya nos adelantaba incluso en la etapa efímeramente triunfante del ataque masculino, cuando el enamorado, aunque eficaz en su escalada de la torre, en cierto momento resbalaba por no haber prestado atención a la señal. ¿Por no haber sopesado adecuadamente, quizá, la disparidad de fuerzas? ¿Por no haber reconocido de antemano el mayor poder de la dama y de su cámara frente a su escala viril? En todo caso, el avezado militar Manrique parece denunciar aquí, oblicuamente, un defecto de aquella virtud que todos los tratados medievales de caballería definen como capital en el soldado: la prudencia, la cordura, el buen sentido ${ }^{9}$.

${ }^{8}$ Esta doble morfología simbólica del castillo, que opera por igual como sumidad y como interioridad, como altura y como interior, es observada por Gaston Bachelard en la simbología de toda casa, que integra asimismo un arriba vertical y un adentro central: «La casa es imaginada como un ser vertical. Se eleva. Se diferencia en el sentido de su verticalidad. Es uno de los llamamientos a nuestra conciencia de verticalidad. La casa es imaginada como un ser concentrado. Nos llama a una conciencia de centralidad. [...]. La verticalidad es asegurada por la polaridad del sótano y de la guardilla. Las marcas de dicha polaridad son tan profundas que abren, en cierto modo, dos ejes muy diferentes para una fenomenología de la imaginación. En efecto, casi sin comentario, se puede oponer la racionalidad del tejado a la irracionalidad del sótano [...]. El sótano se considerará sin duda útil. Se le racionalizará enumerando sus ventajas. Pero es ante todo el ser oscuro de la casa, el ser que participa de los poderes subterráneos. Soñando con él, nos acercamos a la irracionalidad de lo profundo. [...] Los pisos altos [...] son edificados por el soñador, él los reedifica bien edificados. Con los sueños en la clara altura estamos, repitámoslo, en la zona racional de los proyectos intelectualizados» (Bachelard 1965: 51-52). La dialéctica bachelardiana tejado/sótano se corresponde a la perfección con la durandiana diurno/nocturno, y ambas expresan la polaridad que subyace en el poema de Manrique entre la racionalización de un deseo de conquista, expresada como esperanza y proyecto -el ascenso por la escala, la búsqueda de la sumidad del castillo- y la irracionalidad de la derrota final, expresada como destino y pasión -el cautiverio en el interior del castillo--

${ }^{9}$ Dictamina Ramón Llull: «Prudencie es virtut per le qual hom ha conexense de be e de mal, e per le qual hom ha saviese a esser aymador del be e a esser enamich del mal; e prudencie es ciencie, per le qual hom ha conexense de les coses esdevenidores ab les coses presents; e prudencie es con per alcunes cauteles e maestries sab hom squivar los dampnatges corporals e spirituals: on con los cavaylers sien per encalsar e destruyr los mals, e cor nuyls homens nos meten a tants de periyls, con cavaylers, qual cose es plus necessarie a cavayler, que prudencie? [...]; cor mes batayles son vensudes per maestrie e per seny que per moltitut de gents ni de guarniments ni de cavaylers» (Llull 1985: VI, 7, 58); «Cavaylerie e ardiment nos conven sens saviese e seny: 
Tras la ironía de una conquista que se revela al cabo como derrota, el texto nos depara una segunda peripecia, también irónica o paradojal, pues el cautivo caballero acaba viendo en su captura y en su prisión a manos de la dama no una desdicha, sino una felicidad: así, si la victoria inicial se convirtió finalmente en derrota, la derrota muta asimismo de rostro para despojarse de su toda su esperable e inherente tristeza y revestirse de dicha y alegría: «y en hallándome cativo / y alegre de tal prisión, / ni me fue el plazer esquivo, / ni el pesar me dio motivo / de sentir mi perdición» (vv. 61-65). Entiéndase así: la alegría del caballero no se debe a que finalmente en esa prisión de amor haya accedido, siquiera como vencido y cautivo, como parte sometida y dominada, a la bienquerencia de su dama, a los favores de una enamorada que acepta su amor y lo retribuye, sino a una esperanza irracional e infundada en recibirlos -de nuevo falla su prudencia-, prontamente defraudada, con lo cual sucede una nueva y final peripecia que arroja al caballero escalador y cautivo, ahora sí, a su definitiva tristeza:

\author{
Mas mi dicha, no fadada \\ a consentirme tal gozo, \\ se bolvió tan presto irada \\ que mi bien fue todo nada \\ y mi gozo fue en el pozo \\ Robome una niebla oscura \\ esta gloria de mis ojos, \\ la cual por mi desventura \\ fue ocasión de mi tristura \\ y aun la fin de mis enojos. \\ Cuál quedé, pues, yo quedando \\ ya no hay mano que lo escriva,
}

cor si ho fassien, follie e ignorancie se covenxien ab l'orde de cavaylerie» (ibid. II, 18, 22-23). El rey Alfonso asocia simbólicamente en la Partida Segunda la virtud de la cordura con las armas defensivas del caballero y con el mango de su espada: «Ca bien assi como las armas que el ome viste, para defenderse, muestran cordura, que es virtud que guarda de todos los males que le podrian venir por su culpa; bien assi muestra esso mismo el mango del espada, que ome tiene en el puño: ca en quanto assi lo touiere, en su poder es de alçalla, o de baxalla, o de ferir con ella, o de la dexar» (Alfonso el Sabio 1848: II, xxi, 4, 468). Don Juan Manuel, por su parte, enumera una serie de utilidades del seso que el caballero debe tener siempre presentes a la hora de medir fuerzas con el enemigo, y que parecen apuntar directamente a lo que el enamorado de nuestro poema no tomó en debida consideración al enfrentarse al castillo de su dama: «Otrosí el seso le amostrará cómmo et quándo et contra quáles personas deve seer sofrido et manso et de buen talante, et cómmo et quándo et contra quáles personas deve seer bravo et esforçado et cruel [...]; otrosí le mostrará cómmo deve començar la guerra et la contienda non podiendo escusar, et cómmo se pare a ella et de que la oviere començado; et cómmo escusará de la començar sin su mengua o sin su vergüença, et cómmo saldrá della guardando estas cosas. Et otrosí cómmo debe guerrear quando oviere él mayor poder que su contrallo, [o su contrallo] lo oviere mayor que él. Et cómmo debe fazer quando cercare el lugar muy fuerte, o non tanto, o cómmo se debe defender si fuere cercado; et cómmo debe para hueste si oviere de lidiar o con más o con mejores que los suyos» (Don Juan Manuel 1975: XIX, 260-261). 
ca si yo lo vo pintando,
mis ojos lo van borrando
con gotas de sangre biva.
La crueza de mis males
más se calla en la dezir
pues mis dichos no son tales
que igualen las desiguales
congoxas de mi bevir $(\mathrm{I} 76-95,6)$.

Es en este desenlace donde se nos brinda la clave, finalmente, para decidir a cuál de los dos regímenes simbólicos involucrados, el diurno de la ascensionalidad o el nocturno de la interioridad, pertenece en su integridad el poema. Pese a que el triunfo final ocurre en la nocturnidad de la cámara, en el interior deglutivo del castillo, no es este el régimen imaginario dominante y determinante para la semántica global del texto, sino el diurno, porque es con la imagen diurna del ascenso vertical que se asocia inequívocamente la idea de bien, de felicidad y de positividad. Lo nocturno se impone al cabo, pero se impone como un mal; vence fácticamente, pero no axiológicamente: el caballero se empeña en ver un bien en esa cárcel, en esperar aun entre prisiones los favores de su amada, pero estos no le llegan, y no le cabe sino hundirse en la tristeza y la congoja. Toda su fuerza, toda su proyectada dicha, todo su motivante e impulsor deseo se concentraron en la etapa diurna, luminosa, vertical y ascensional de la subida a la torre por la escala: ahí es donde residió, efimeramente y siquiera como proyecto y expectativa, la felicidad del caballero. Una vez llegado al interior del castillo y deglutido por él, y pese a su breve moción de obstinada esperanza, la alegría desaparece, la esperanza muere, y todo su gozo fue en el pozo. En el régimen nocturno, los interiores que devoran lo hacen para proteger y nutrir, cual vientres que gestan un nuevo nacimiento y dan origen a una vida mejor y renovada -como ocurre en la noche de los místicos, como ocurre con Jonás engullido por la ballena-; aquí, por el contrario, la cárcel del castillo es definitiva y fatal, el vientre devora no para nutrir sino para disgregar, y no hay vida nueva posible después de esta muerte que el propio poeta sanciona como tal:

Mas después de atormentado con cien mil agros martirios, diré cuál amortajado quedo $^{10}$, muerto y no enterrado, a escuras, sin luz ni cirios (I 96-100,6)

${ }^{10}$ Apartándonos de la lectura conservadora de Beltrán y de todos los editores, preferimos enmendar la lección queda del Cancionero General de 1511, en razón de que con toda evidencia es la primera persona del poeta quien ejecuta la acción de morir y quedar amortajado e insepulto. 
En el segundo poema que consideraremos lo más destacable es la sorprendente inversión de roles arquetípicos que presenta:

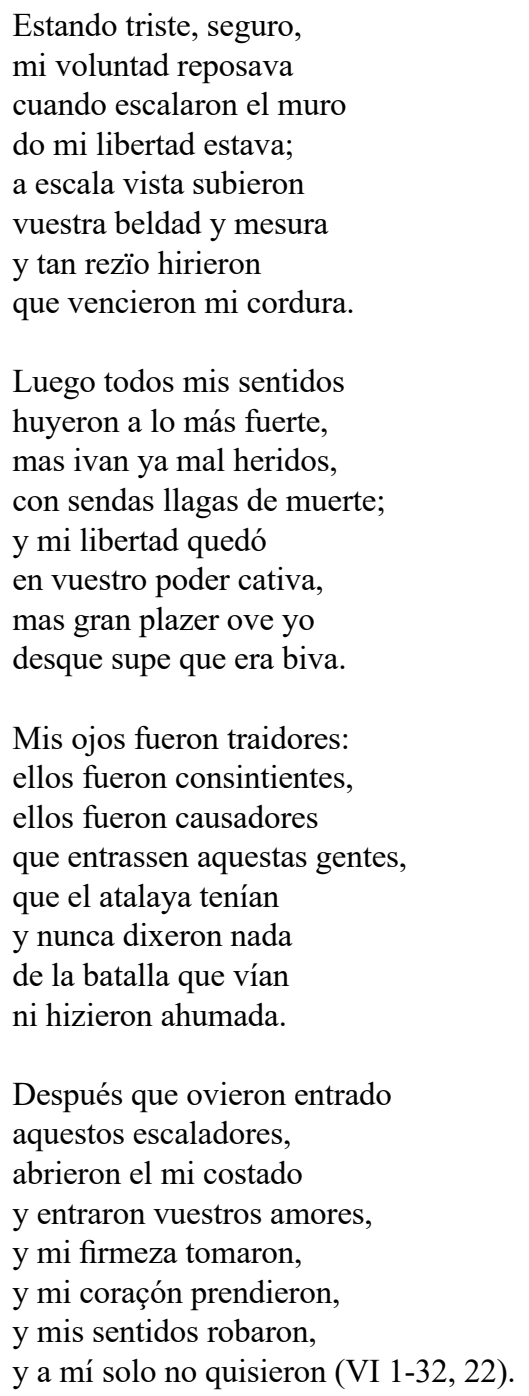

Como en el texto anterior, el castillo está implícito, sugerido apenas detrás de ese muro que protege al caballero y que escalaron la belleza y la mesura de la dama a escala vista. La imagen es, de nuevo, diurna ascensional, y de nuevo nos enfrentamos al tópico gesto del asalto al castillo mediante la escalada de sus torres o de sus altos muros, pero lo extraordinario es que quien ejecuta aquí el movimiento vertical ascendente no es ya el caballero - estático y encerrado, por el contrario, en el interior del castillo- sino la dama, o mejor, mediante analítica 
metonimia alegorizante, la beldad y la mesura de la dama. La situación activa del ascenso, arquetípicamente diurna y masculina, se predica aquí del actante femenino, y la situación pasiva del encierro y el reposo, nocturna y femenina de suyo, se adscribe al actante masculino ${ }^{11}$. Se trata, de todos modos, de una estrategia actancial distinta para arribar al mismo resultado y a idéntico desenlace, pues al igual que veíamos en el poema I, quien triunfa en la guerra es siempre la dama, y poco importa si lo logra como defensora de su castillo atacado, o como atacante de un castillo muy mal defendido por el caballero. Hay quien ha visto en este castillo conquistado por la dama una alegoría del cuerpo del caballero (Domínguez 1988: 34-36); en realidad, semejante expositio allegorica se queda corta, pues los distintos elementos que componen la imagen no son solo corporales, sino también psíquicos y espirituales, al igual que las armas ofensivas de la dama: lo que reposa en el castillo en la situación inicial es la voluntad del caballero, y lo que se encierra en él es, como ya hemos dicho, su libertad, ambas realidades no corpóreas; los atacantes que componen las huestes de la dama son la beldad -corpórea-, y la mesura -incorpórea-; más adelante aparecen, sí, elementos corporales en el andamiaje defensivo del castillo -los sentidos del caballero, que huyen malheridos, sus ojos traidores, que no le dieron aviso del inminente ataque pese a haber estado atalayando, su costado abierto cual brecha en el muro, acaso la imagen donde más clara y físicamente puede percibirse la doble isotopía entre el sentido bélico y el erótico de la acción narrada-, pero quienes entran por esa brecha-herida abierta en el muro-costado del caballero son los incorpóreos y espirituales amores de la dama atacante, y lo que resulta finalmente cautivo del caballero derrotado son su corporal coraçón junto a su espiritual firmeza. Como vemos, detrás de este esquema en extremo analítico, de esta segmentada alegoría llevada adelante por tan numerosos agentes atacantes y defensores, el yo lírico acaba disociándose hasta el punto de su desaparición $^{12}$; no se trata en absoluto de una falla compositiva de Manrique, ni de un efecto inevitable de los moldes retóricos usuales en este tipo de poesía, sino de un hábil recurso expresivo que dobla y enfatiza el contenido semántico desarrollado por la historia: si el caballero es vencido, si pierde su cordura, sus sentidos, sus ojos, su firmeza, su corazón y su libertad, es porque todos estos elementos corporales, psíquicos y espirituales nunca llegaron a constituir en él una unidad, un sujeto; si

${ }^{11}$ Battesti-Pélégrin (1984: 21-22) señala con acierto el carácter paradójico de la alegoría mediante la cual el poeta alude al encierro del caballero en el interior del castillo: escalaron el muro / do mi libertad estava. Lo que encierra el caballero tras el muro es su libertad, aquello que, por definición, no debe ni puede ser encerrado so pena de dejar de ser lo que es.

${ }_{12}$ «L'intellect, l'affect, les sens sont dissociés; le "moi" est autre chose. Extraordinaire analyse psychique; sorte de distanciation soulignée par la récurrence de "mi", "mis". Le seul "yo" du texte, "mas gran plazer ove yo", affirme la jouissance dans la douleur» (BattestiPélégrin 1984: 23). 
la dama lo ha finalmente conquistado, ha sido porque no halló frente a ella una real persona capaz de resistirle ${ }^{13}$. No se hace un hombre con un conjunto de órganos, percepciones y propiedades del alma a tal punto inconexos y disgregados. Si hemos de perseverar en la metáfora guerrera que da sustento al relato, bien podríamos decir que la plaza cayó porque sus fuerzas defensivas carecieron de coordinación, de organización y de comando unificado; carecieron de caudillo, o en todo caso contaron con un caudillo sin la habilidad necesaria para ganarse la lealtad de su tropa: por eso sus ojos lo traicionan. Podría argüirse en contra de este análisis que también el yo de la dama atacante aparece disociado, pues esta se presenta al asalto bajo la forma alegórica también fragmentada de una beldad y una mesura que escalan el muro y unos amores que penetran en la brecha del corazón, pero la lista de elementos que metonímicamente aluden a su persona resulta, como bien se ve, mucho más breve que la de los que aluden al caballero: a todas luces, el sujeto del varón conquistado aparece mucho más atomizado y disgregado que el sujeto de la mujer conquistadora, y en tal diferencia radica en última instancia el porqué de quién vence y quién no.

$\mathrm{Al}$ igual que en el poema anterior, tampoco en este hay verdadero gozo; si en aquel la alegría era efímera y proyectiva, una mera esperanza a futuro experimentada fugazmente durante la etapa de la escalada, en este el plazer apenas despunta, tímida y brevemente, bajo el aspecto de consuelo o resignación, cuando el caballero advierte que su libertad, pese a haber sido hecha prisionera, sigue con todo viva (13-16). No habiendo, pues, ninguna emergencia consistente y duradera de un bien, de una positividad inequívocamente postulada como poseída, y siendo por el contrario todo el desarrollo narrativo del poema una amenaza primero y una derrota al cabo para el caballero, la dialéctica de los regímenes diurno y nocturno no puede resolverse, como en el texto previo, a favor del primero, sino queda en permanente y tensa indefinición. En efecto, en el poema I existía al menos una transitoria esperanza de bien durante la etapa ascensional que permitía adscribir el texto al régimen diurno, en tanto en este poema VI no hay atisbo ni de esperanza ni de fruición, ni en la etapa de la amenaza que asciende por el muro, ni en la etapa final del cautiverio. El caballero no ha hallado protección, alimento y defensa ni en la sumidad del alto muro, pues fue escalado, ni en la interioridad del castillo, pues fue penetrado igual que su costado. Nada en el castillo

${ }^{13}$ El texto mismo parece convalidar esta exégesis, pues el triunfo final de la amada en su conquista del amante se expresa mediante la paradoja de que, habiendo los amores de aquella apresado la firmeza, el corazón y los sentidos de este, no lograron con todo apoderarse de su persona (y a mí solo no quisieron). Uno de los efectos más característicos del amor es la escisión o enajenación del sujeto, que queda disociado de las potencias y facultades que lo constituyen y deberían identificarse con él: los amores de la dama no quisieron al caballero, sencillamente, porque el caballero no existe, se anula y desintegra en la emergencia fragmentada de sus propias facultades sensoriales, afectivas y espirituales. 
le ha resultado favorable y bienhechor, sino todo en él, su altura diurna y su interior nocturno, lo han traicionado y defraudado.

Pero si no cabe ya establecer con precisión para el poema un carácter predominantemente diurno o nocturno, sí procede en cambio analizar su dinámica simbólica mediante un esquema de las fuerzas direccionales, pues los sucesivos movimientos que van pautando la historia narrada se articulan entre sí mediante un claro juego de vectores de distinta orientación, enmarcados por una situación inicial y otra final de estatismo, de la siguiente manera: 1) situación inicial estática: el caballero se encuentra seguro, aunque triste, en su castillo, donde reposan su voluntad y su libertad ${ }^{14}$; 2) vector vertical ascendente: la beldad y la mesura de la dama escalan el muro del castillo; 3 ) vector horizontal centrífugo: los sentidos del caballero huyen fuera del castillo; 4) vector horizontal centrípeto: debido a la traición de los ojos vigías, que no avisan de su llegada, los amores de la dama penetran en el interior del castillo-costado del caballero, acto definitorio de la conquista: 5) situación final estática: reproduce la situación inicial, con el caballero igualmente encerrado en el interior de su castillo, solo que ahora, enamorado, ya no es dueño de su corazón, su voluntad y su libertad, con lo cual su residencia y reposo constituyen una enajenación y una prisión.

El tercer poema cortés que comentaremos a propósito de la metáfora del castillo es el número VIII de la ordenación de Beltrán, titulado precisamente Castillo de Amor. A simple vista puede parecer que el autor recurre una vez más a la misma alegoría bélico-militar ya conocida para representar la índole de su amor, pero se trata ahora de un grado de abstracción alegórica mucho mayor que la de los casos a anteriores. Si en los poemas ya analizados el castillo atacado y las huestes atacantes se identificaban, respectiva e inversamente, ya con la dama asediada y el caballero conquistador (poema I), ya con el caballero enamorado y la dama seductora (poema VI), ahora el castillo pasa a simbolizar una realidad mucho menos concreta y del todo impersonal, la fidelidad que el amante guarda a su amada, la cual le permite defenderse de los asedios de fuerzas enemigas también impersonales como el olvido o la traición, atacantes del castillo (Piña Pérez 2020: 88-89). Dicho en términos más claros: el castillo ya no es ni el amante ni la amada, sino el amor mismo, o mejor dicho, la fortaleza de ese amor construida por ambos (BattestiPélégrin 1984: 20-21); en consecuencia, su identificación no es con una

${ }^{14}$ Con respecto al verso inicial del poema, estando triste seguro, Serrano de Haro y Morrás, en sus respectivas ediciones, arriesgan la plausible opinión de que el adjetivo triste no puede yuxtaponerse con seguro, a causa de que la expresión resultante sería abiertamente contradictoria e ilógica: no puede el yo lírico estar a la vez triste y seguro, y menos aún si en el verso siguiente se nos dice que su voluntad reposava. Ambos editores juzgan que triste debe tener un valor exclamativo y autovocativo que interrumpe la construcción de gerundio a la manera de una queja, con un significado aproximado de estando, itriste de mi!, seguro... 
persona, con una sustancia individual, sino con una relación interpersonal en la que los roles respectivos de ambos actantes se definen no ya en una oposición de castillo atacado vs. no-castillo atacante, sino en una complementación subordinativa del caballero-vasallo defensor del castillo y la dama-señora del castillo, que coloca a los dos en el adentro de este (Domínguez 1988: 36-37).

Beltrán segmenta el poema en tres partes de tres estrofas cada una, precedidas por una inicial estrofa introductoria; en la primera parte (estr. 2-4) se describen las instalaciones defensivas del castillo, en la segunda (estr. 5-7) el castillo mismo, y en la tercera (estr. 8-10) se pronuncia un juramento de fidelidad que ratifica el sentido de toda la alegoría. Morrás lee el texto en correlación con el poema VI; en ambos se alegoriza el amor del caballero bajo la imagen de una fortaleza, pero en tanto en el VI se representa ese amor en su etapa de establecimiento -las huestes de la dama escalan las murallas del castillo y lo conquistan-, en este poema VIII estamos ya en la etapa de conservación y consolidación de un amor ya establecido desde antes, por medio de su ejercicio leal -quienes intentan tomar ahora, en vano, el castillo son agentes amenazadores y potencialmente destructores de un amor ya existente y fuerte que, cual plaza inexpugnable, resiste-. Veamos las cuatro primeras estrofas:

Hame tan bien defendido, señora, vuestra memoria de mudança, que jamás nunca ha podido alcançar de mí victoria olvidança, porque estáis apoderada vos de toda mi firmeza en tal son, que no puede ser tomada a fuerça mi fortaleza ni a traición.

La fortaleza nombrada está en los altos alcores de una cuesta, sobre una peña tajada, maciça toda de amores muy bien puesta, $\mathrm{y}$ tiene dos baluartes hazia el cabo que ha sentido el olvidar, y cerca a las otras partes un río mucho crescido que es membrar. 


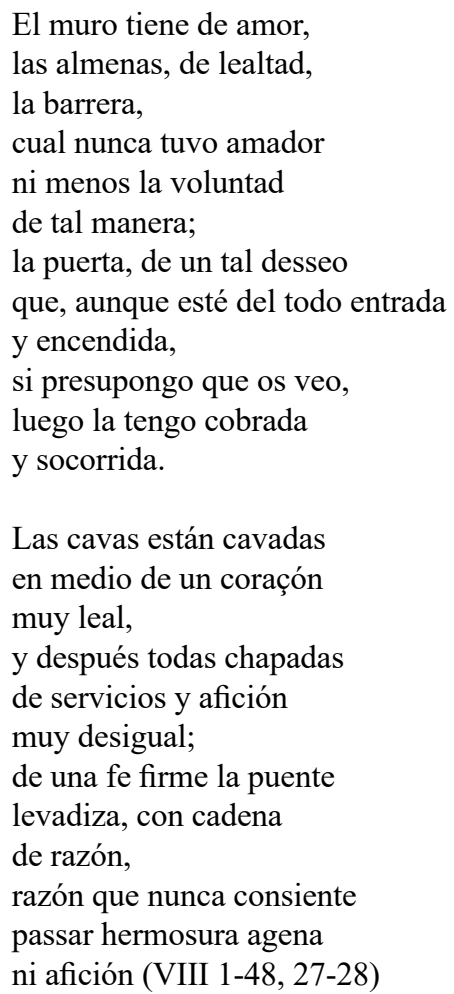

Todos los elementos defensivos del castillo se identifican con virtudes o propiedades del vasallo enamorado, según una lista de alegorizaciones claramente señaladas; todas ellas apuntan a proteger el amor que vincula al vasallo con la señora de dos enemigos tópicos de toda relación cortés: la olvidança-hame tan bien defendido, / señora, vuestra memoria / de mudança-, y la traición -que no puede ser tomada / a fuerça mi fortaleza / ni a traición-. El castillo así defendido, igual que en los poemas anteriores, contempla un aspecto diurno ascensional y se define como una sumidad, pero esta vez la elevación no se identifica tanto con las torres o con la altura de los muros, sino con el accidente orográfico sobre el cual se erige el edificio - está en los altos alcores / de una cuesta, / sobre una peña tajada-, que supone una primera defensa; las demás se enumeran prolijamente, acompañadas de sus correspondientes expositiones allegoricae: dos baluartes $=$ defensas contra el olvido; un rio $=$ la memoria -el membrar-; el muro = el amor; las almenas = la lealtad; la puerta $=$ el peligro de un deseo impropio ${ }^{15}$; las cavas $=$ la fidelidad del corazón; el enchapado de las cavas = los servicios del caballero a su

${ }^{15}$ El sentido de los versos 31-36, algo intrincado, es el siguiente: 'aunque el deseo de otra mujer haya pasado ya por la puerta y haya invadido el lugar (esté del todo entrada / y encendi$d a$ ), me basta con recordar o imaginar vuestra figura (si presupongo que os veo) para expulsar 
dama y su afición a ella; el puente levadizo = la fe; las cadenas que levan el puente $=$ la razón que impide el paso de atacantes tales como la belleza o la afición de otras damas. Por sobre tanta especificación funcional, lo que aúna y reúne a todas estas defensas en un solo efecto de sentido es su inquebrantable eficacia -que habrá de contrastar por cierto, según veremos, con la debilidad operativa de las defensas del castillo abatido por la flecha de la muerte en las Coplas-.

La siguiente sección pasa de las defensas exteriores a los elementos morfológicos del castillo en sí, como las ventanas y las torres; de las primeras se dice:

Las ventanas son muy bellas,
y son de tal condición
que dirá aquí:
que no pueda mirar dellas
sin ver a vos en visión
delante mí (VIII 49-54, 28-29)

Quizás asome en estos versos, tenuemente, un viejo simbolismo tradicional, cuyos rastros doctrinarios pueden hallarse tanto en el Hinduismo cuanto en el Islam, y que en la gran poesía de Occidente está presente -entre otros sitios- en las Metamorfosis de Ovidio, en las Églogas de Virgilio y en el Cántico espiritual de San Juan de la Cruz; se trata de la idea de que el verdadero amante, cuando se mira sobre una determinada superficie clara -aguas quietas, cristales límpidos, espejos o metales pulidos-, en lugar de ver reflejado su propio rostro lo que ve es el rostro de la persona amada. El símbolo remite al mito de Narciso, pero contra la lectura trivializante que afirma que el joven de ese nombre se enamoró de sí mismo de tanto verse espejado en las aguas de una fuente, la lectura mítica profunda nos dice que sucedió al revés, que por estar ya de antemano enamorado de sí mismo, autocentrado en su propio yo, solo vio su rostro reflejado en las aguas, y no pudo ver el de ningún otro amado que no fuera él. Manrique no lo aclara, pero bien pueden suponerse en estas ventanas de su castillo, que son muy bellas, unos cristales debidamente límpidos y espejados sobre cuya superficie el caballero vea no su propio rostro, sino el de su amada -que no pueda mirar de ellas / sin ver a vos en visión / delante mí- (Suárez Pallasá 1994: 67-87; 1995: 111-140). En todo caso, y más allá de la apelación al simbolismo tradicional de la visión del ser amado a través del reflejo luminoso ${ }^{16}$, cabe establecer la identificación alegórica ventanas $=$ presencia física de la amada. En

a ese deseo enemigo e invasor y recuperar el dominio del castillo (luego la tengo cobrada / y socorrida)'.

${ }^{16}$ Recuérdese la estrofa duodécima del Cántico espiritual de San Juan de la Cruz (1993: 251): « ¡O christalina fuente, / si en esos tus semblantes plateados / formases de repente / los ojos deseados / que tengo en mis entrañas dibuxados!». 
cuanto a las torres, hay una, muy alta, que alegoriza la verdad del amor del poeta $(61-72,29)$, y hay otra que se presenta así:

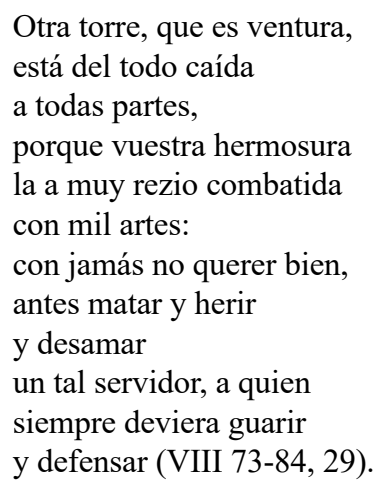

Esta segunda torre, que representa a la ventura del caballero, está caída, derruida a causa de los simbólicos ataques que la hermosura de la dama le ha propinado; el amante hiperboliza de este modo los efectos devastadores de la belleza de su señora, que lo ha enamorado al punto de causarle la desventura, y le desliza un velado reproche por atacarlo de esa manera, en vez de defender - defensar-a quien es su leal servidor cortés. Vemos así por un momento, fugazmente, reaparecer el esquema del anterior poema VI, en el que la dama atacaba y doblegaba al caballero; en el seno de una alegoría cuyo planteo hace del castillo la representación del amor sólido y actual de ambos, y que se identifica por tanto con la relación entre los dos más que con uno u otro de ellos individualmente, despunta de improviso la nota discordante de una sombra en esa unión y de esa relación de aparente plenitud, de una queja, de una reconvención, de un atisbo de debilidad, que a la vez que nos remite a una posible y conjetural prehistoria de la acción aquí narrada -el momento en que el actual amor se estableció, mediante la conquista de la ventura de él por la hermosura de ella-, puede estar profetizándonos también futuros conflictos y quiebres en este peculiar pacto vasallático cortés. En todo caso, lo que viene a decirse en esta sorpresiva grieta semántica es que no siempre el castillo fue fuerte, que una de sus torres logró ser derribada, y que lo fue por obra y ataque de su actual señora: mientras el castillo fue dominio del caballero, estuvo signado por la debilidad y la fragilidad; solo se hizo sólido y fuerte cuando resultó conquistado por el amor que trajo consigo la dama, cuya fortaleza bastó entonces para tomarlo y basta ahora para asegurar su resistencia. Si bien la fortaleza del castillo radica en el amor entre ambos, estos pocos versos ponen en evidencia que quien aporta la mayor y verdadera cuota de pujanza y de fuerza en la relación es la parte femenina, quien de suyo ejerce la potestas del señorío, y de quien en rigor derivan las potencialidades defensivas masculinas que la sirven. 
La estrofa octava $(85-96,30)$ enumera una serie de provisiones o fortalezas que hacen inexpugnable al castillo frente a cualquier ataque exterior -cuidados, males, dolores, angustias, fuertes pasiones, penas muy desiguales, temores-, que no pueden fallescer aunque el asedio dure mil años. En la siguiente estrofa $(97-108,30)$ se nos descubre una tercera torre antes no mencionada junto a las otras dos, la torre de omenaje, la más importante de todo castillo, donde se halla clavado el estandarte que identifica heráldicamente al señor -señora en este caso-que manda en el sitio, y que contiene una señal enigmática sobre su identidad:

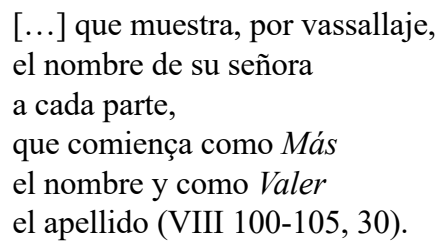

En la estrofa novena y final (109-120, 30-31) es donde reside específicamente el juramento de fidelidad del caballero a su señora, conforme al imperativo cortés de la lealtad (Compagno 2008: 129-130); por él se compromete solemnemente el amante, reconociéndose vasallo de su amada, a no entregar ni rendir el castillo que a ella le pertenece ni bajo tormento, ni bajo amenaza de muerte, ni aunque el mismo dios del amor se lo ordene. La conclusión viene de este modo a reforzar la idea que ya veíamos en la previa estrofa séptima: que el origen de la fortaleza del castillo radica en la amada, que es ella, mediante la sujeción y fidelidad amorosas que despierta en su vasallo, la que vuelve fuerte y capaz de resistir ante cualquier ataque a aquel mismo que antes, solo y carente de tal señorío transformador y meliorativo, se había mostrado débil y vulnerable.

Podemos ahora extraer dos notas conclusivas sobre los tres poemas comentados. La primera tiene que ver con la plena operatividad observable en todos ellos, a través de la alegoría de la defensa y eventual toma del castillo, del tradicional esquema feudal y cortés que estipula el carácter descendente de toda virtud, que baja del señor al vasallo -aquí, de la señora al caballero enamorado-. En la casuística cortés es siempre la dama quien hace fuerte, leal, diestro y resistente al caballero que la sirve; toda virtud procede de ella, ella mueve a su amante, quien caería fácilmente en acedia o debilidad sin el amor de su dama. Los libros de caballerías ejemplifican esta situación anómala mediante el motivo tópico de las penitencias de amor -de Amadís en Peña Pobre, por ejemplo-, y en una ficción sentimental como Cárcel de amor la fortaleza que resulta inherente a la actividad del caballero es una de las veinte razones por las cuales los hombres quedan obligados con las mujeres, ya que es de 
estas de donde procede, únicamente, dicha virtud ${ }^{17}$. Puede decirse, latamente, que la señora, en cuanto amor, es para el caballero la causa final de su aventura, esto es, de su vida misma (Suárez Pallasá 2006: 1-10), y que lo mueve hacia sí como las causas finales mueven y orientan todas las cosas a su realización y consumación: l'amor che muove il sole e le altre stelle. Pero este contenido tópico del código cortés no resulta, en definitiva, sino de la adaptación al ámbito erótico de mucho más viejas normas feudales, según las cuales la asimetría propia de la relación entre el señor y el vasallo impone una condición necesariamente descendente de la virtud. Podemos recordar aquí, desde luego, el célebre verso 20 del Cantar de Mio Cid: Dios, qué buen vassallo si oviesse buen señor. Si la enamorada cortés es quien hace fuerte a su amante, porque ella misma lo es antes en cuanto sede de ese amor de donde dimana toda virtud, el señor feudal es quien hace bueno al vasallo, porque él mismo lo es en cuanto sede del poder de donde dimanan todo derecho y toda acción. En nuestros tres poemas analizados, este carácter descendente de la virtud, esta deriva de todo bien desde la dama hacia el caballero, se pone en evidencia de maneras distintas, pero todas ellas concurrentes en la misma interpretación. En el poema I el caballero ataca el castillo y la dama, residente en este, resiste y no es conquistada, porque es ella, en cuanto señora, la verdadera sedes fortitudinis, y como no existe aún relación de amor establecida entre la amada y su amante, este resulta débil e impotente para doblegar las murallas que guardan a ese tesoro: escala la torre, pero cae preso en la cámara. En el poema VI los roles se invierten, y es la dama quien ataca el castillo habitado por el caballero; como este, de nuevo, se halla solo allí y carece de un vínculo de amor de donde pueda extraer fuerzas para la resistencia, cae doblegado ante la fuerza propia de la dama que lo asalta. Finalmente, en el poema VIII los principios femenino y masculino sí se encuentran unidos por la relación de amor, $\mathrm{y}$ es de este amor que los vincula de donde procede la fortaleza que convierte al castillo habitado por ambos en inexpugnable; pero por la breve prehistoria que se nos narra en la estrofa séptima vemos claro que quien comunica su fuerza al amor común de la dama y el caballero es la primera, pues cuando tal amor no estaba aún establecido y los amantes se hallaban separados, fue la mujer quien con su sola virtus resultó capaz de doblegar al varón solitario y asediado en el castillo, derribando su torre. Cuando varón y mujer se encuentran separados y no vinculados por el amor, el varón es el débil y la mujer es la fuerte, sin importar cuáles

${ }^{17}$ «[...] al que fallece fortaleza ge la dan, y al que la tiene ge la acrecientan: házennos fuertes para sofrir, causan osadía para cometer, ponen corazón para esperar. Cuando a los amantes se les ofrece peligro se les apareja la gloria, tienen las afrentas por vicio, estiman más el alabança del amiga quel precio del largo bevir. Por ellas se comiençan y acaban hechos muy hazañosos; ponen la fortaleza en el estado que merece. Si les somos obligados, aquí se puede juzgar» (San Pedro 1999: 44, 136). 
sean los roles actanciales desempeñados por cada uno: si el caballero ataca, fracasa en su ataque, y si defiende, fracasa en su defensa; por el contrario, la dama se impone siempre, ya sea atacando (poema VI, prehistoria del poema VIII), ya sea defendiendo (poema I). Cuando la pareja obra de consuno dentro de una relación de amor ya establecida, la fortaleza que la vuelve invencible deriva en instancia inmediata de ese amor común, pero en instancia última (prehistoria del poema VIII) derivará siempre del actante femenino, única y verdadera causa amoris $\mathrm{y}$, por consiguiente, causa virtutis.

La segunda nota conclusiva tiene que ver con la dialéctica de los regímenes simbólicos. Si veíamos que en el poema I el régimen diurno resultaba más determinante que el nocturno -pese al desenlace engañoso- en la caracterización imaginal del texto, en razón de que el único bien atisbado e intencionalmente gozado radicaba en la etapa del ascenso por la escala y no en la final inhabitación en la cámara, y que en el poema VI ambos regímenes permanecían en irresuelto equilibrio conclusivo a causa de que no podía en rigor postularse ningún bien, ni esperado ni alcanzado, ni futuro o posible ni presente y real, asociado a ninguna de las etapas ni a ninguna de las dimensiones espaciales involucradas, hemos de reconocer en el poema VIII un inequívoco dominio del régimen nocturno. Todo en él, en efecto, es femenino, cerrado, acogedor e interno. Las defensas exteriores que se describen solo cuentan en función del interior que postulan y defienden, el amor que reina poderoso y fuerte lo hace desde ese adentro del castillo donde los enamorados cohabitan, y no desde una sumidad o altura que deba alcanzarse mediante actividad y esfuerzo diurnos; todo es posesión plena -a excepción hecha de la fugaz remembranza del caballero acerca del momento en que su dama lo conquistó derribándole la torre-, y todo ese estado de plenitud, fortaleza, fidelidad y reposo encuentra su origen, su clave y su reaseguro en un señorío femenino. Si las defensas y las armas que protegen el castillo, de suyo diurnas, son fuertes y eficaces, es porque hacen derivar esa eficacia y esa fuerza de una virtud del todo interior, del centro recóndito e inexpugnable, del corazón amoroso y nocturno del castillo; si el diurno caballero es buen defensor, lo es porque obtiene su bondad defensiva de la buena señora nocturna que lo ama -concédale o no sus favores concretos- y a quien ama. La inaccesibilidad del arriba es efecto de la fecundidad del adentro. Es el interior afectivo y pasivo la matriz que engendra, nutre y comunica bondad al exterior activo y bélico. Es el amor el fundamento del poder.

\section{LA METÁfora DEL CASTILlo EN LAS COPLAS A LA MUERTE DE SU PADRE}

En la estrofa 23 de las Coplas Manrique opera un cambio importante en su estrategia elocutiva: si hasta aquí había venido ocupándose de la 
muerte como un objeto, aludiéndola en tercera persona, ahora pasa por primera vez a interpelarla como un tú, confiriéndole entidad personal mediante el recurso de la prosopopeya, y dando un primer paso en el camino de su máxima personalización y concreción, que habrá de ocurrir en los tramos finales del poema, cuando la muerte pase de tú a yo y asuma ella misma la palabra como locutora de un discurso en el que, finalmente, revela su verdadera entidad y permite por tanto la comprensión existencial y vivencial -ya que no la intelección meramente racional-de su misterio (González 2019b: 8-22; Gómez Galán 1960: 212-227). Tantos duques excelentes, / tantos marqueses y condes / y varones / como vimos tan potentes, / di, muerte, ¿dó los escondes / y traspones? (Coplas xxiii 265-270, 123-124). Continuando con esta apelación a su fuerza destructora en segunda persona, la estrofa siguiente es la que presenta la imagen del potente castillo abatido, con todas sus defensas, por la sola y en apariencia débil flecha de la muerte:

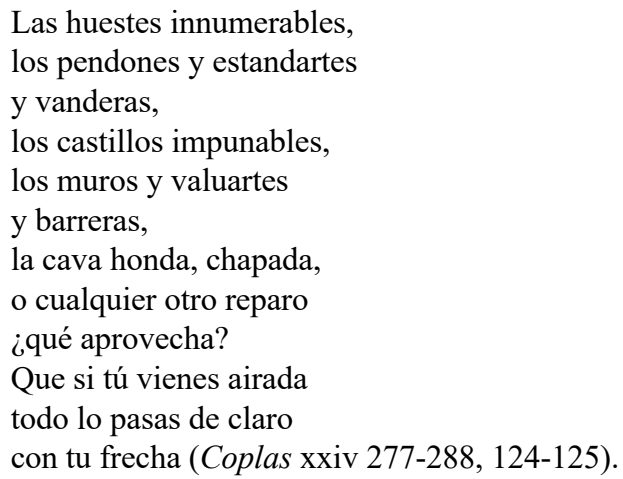

Frente al aislado castillo de los tres poemas amatorios, estamos aquí ante un desvaído plural castillos, que desrealiza y debilita aún más la fuerza y la entidad de esa mole arquitectónica que, contra lo esperable, no puede al cabo resistir ante la potencia ontológicamente mayor de una flecha singular y única, de «la» flecha ${ }^{18}$. Estamos nuevamente, como en los casos anteriores, ante una guerra, pero quien ejerce ahora el poder

${ }^{18}$ Ya Salinas se regocijaba ante la eficacia de esta desmesurada antítesis entre la inútil solidez del castillo y la delicada y mortífera flecha: «Alinea el poeta ante nuestros ojos lo que en la Edad Media era el mayor signo de fuerza y de poder: el arsenal guerrero. [...] En el siglo XV solo se alzan como símbolos de potencia la catedral y el castillo. En una, el hombre, si bien manifiesta su poder, lo humilla al servicio de Dios. En el otro el poder humano se enraíza en lo terrenal y en lo material; y las fortalezas, los castillos, los armamentos se imponen a las almas amedrentadas como fuerzas incontrastables. Por eso Jorge Manrique las encara a la muerte. [...] El poeta acumula todas estas apariencias de poder en 8 versos para oponerlas luego a una acertadísima imagen de la muerte representada en algo tan breve, ligero y agudo como es una flecha. Esa es la flecha sobrenatural que puede con todo y todo lo atraviesa, cuando la dispara la voluntad de la muerte. Impresionante efecto, sentir que tantas masas de piedra, tantas láminas de hierro no valen contra una, contra una sola saeta, y que el gran peso, el enorme poderío 
mayor, el que determina la victoria, no es el amor, sino la muerte, la nueva y superior dama, la máxima señora, la absoluta manifestación de la virtus femenina. Si esta se revelaba en las poesías anteriores como amor, lo hace ahora como muerte, pero tanto en uno como en otro caso el principio femenino es quien detenta el poder y quien necesariamente vence.

$\mathrm{Si}$ en los poemas amatorios coexistían y cooperaban en la figura del castillo, con mayor o menor grado de tensión interna, los regímenes simbólicos de la sumidad diurna y la interioridad nocturna, observamos aquí una desaparición total de la segunda. En esta nueva imagen todo es diurno, todo es exterior, todo fulge y resplandece en el aire y en la luz, así los muros, los estandartes, los pendones, las barreras y las cavas chapadas que han de ser abatidas, como la grácil y voladora flecha que abate todo ese aparato vanamente defensivo ${ }^{19}$. Que la muerte misma, nocturna de suyo, aparezca bajo un emblema netamente diurno y aéreo como la flecha, es todo un hallazgo expresivo y una audaz apuesta semántica ${ }^{20}$. En cierto modo, la muerte se diurniza y masculiniza, se hace ascensional y solar para derrotar al castillo y a esos duques, marqueses y condes tan potentes que también son diurnos y masculinos, pero mucho menos potentes que su vencedora, porque su poder de resistencia ya no está sustentado -como en los poemas corteses- en la fuerza nutricia del amor, sino que consiste en una mera apariencia exterior, en una vanidad, en una ostentación, en una raigal debilidad mal disimulada (González 2020: 142-146).

Esta eficacísima imagen, cuyo logro radica en gran parte en lo concentrado y urgido de su narratio allegorica -frente a los relatos más demorados y débiles que veíamos en los poemas corteses-, no alcanza empero toda su potencia semántica en esta instancia del poema, sino que difiere y remite su consumación al final de la obra, al desenlace de la muerte de don Rodrigo Manrique, con el que establece relación de contraste y co-significación:

de la muerte, se condense y afine todo en esa forma leve de una varilla con la punta acerada» (Salinas 1947: 178-179).

${ }^{19}$ «No hay precaución útil contra la muerte, y así queda claro puesto que la copla aprovecha los elementos bélicos definitorios de la nobleza para presentar a la muerte como un arquero. Ninguno de los signos externos de poderío ni subterfugio defensivo alguno son eficaces ante el arco y las flechas, y Manrique, como guerrero, lo sabía muy bien. Se trata de una imagen de naturaleza semejante a las empleadas en su lírica amorosa, aunque utilizada aquí con una función distinta. De la asimilación tópica del enamoramiento a la agonía -provocada por la belleza indiferente de la dama - se pasa ahora al poderío inescapable de la muerte como contraria letal» (Zepeda 2006: 38; Battesti-Pélégrin 1984: 15). Gilman (1991: 291-292) destaca que muy frecuentemente la muerte era representada en el siglo Xv como un cazador o un arquero, según consta incluso en la misma Danza de la muerte.

${ }^{20}$ Según la arquetipología de Durand (2004: 139-140), la flecha es absolutamente isomorfa de la escala en cuanto elemento ascensional y diurno, solo que mientras esta supone un ascenso esforzado y paulatino, aquella expresa una subida instantánea y sin esfuerzo; también el ala -tanto de aves como de ángeles-y el rayo se asocian, con homólogas funciones, a este complejo simbólico. 
[...] en la su villa de Ocaña, vino la muerte a llamar a su puerta [...] (xxxiii 394-396, 131).

Así, con tal entender, todos sentidos humanos olvidados, cercado de su muger $\mathrm{y}$ de hijos y de hermanos y criados, dio el alma a quien ge la dio [...] (Coplas xl 469-475, 134-135).

El maestre no es alcanzado por la muerte en un castillo, sino en una villa, y dentro de esta, en una casa que, aunque pudiera ser fortificada, se intuye antes como hogar -por los detalles que nos brinda el texto acerca de la familia reunida y la visita amigable de la muerte que llama a la puerta- que como aparato de defensa militar. No estamos ya ante un castillo atacado y abatido, sino ante una casa visitada y brindada: la relación de hostilidad vida-muerte ha mutado hacia una relación de hospitalidad que resulta recíproca, pues si en un primer momento es la vida quien acepta recibir a la muerte y le abre las puertas de su casa, al cabo la relación se invierte, y es la muerte la verdadera morada sin pesar (vv. 50-51), la casa final que habrá de albergar como anfitriona última al viviente-muriente don Rodrigo (González 2019b: 8-22). No estamos por lo tanto ante ninguna imagen bélica ya, sino ante un cuadro hogareño que nos ha de permitir -antes bien, exigir- la reintroducción del capital tema del amor, que parecía -y lo estaba- del todo excluido del símbolo del castillo en la estrofa 24. Si el castillo caía ante la flecha entonces, si su poder se mostraba aparente y falaz, era porque no se fundaba en amor alguno; aquí, por el contrario, la casa no cede ante la fuerza de la muerte, no cae abatida por ella, sino le abre voluntariamente sus puertas, confiada en la fuerza interior que surge del amor, no ya cortés sino familiar y social, que reina en ella y en el que cimienta sus paredes, amor del que dan testimonio tanto los parientes y criados que rodean el lecho de despedida del maestre cuanto aquellos amigos, vasallos y valientes a los que supo corresponder durante su vida:

Amigo de sus amigos,

¡qué señor para criados

y parientes!

¡Qué enemigo de enemigos!

¡Qué maestro de esforçados

y valientes! (Coplas xxvi 301-306, 125). 
La vida del maestre ha sido una vida colmada de amor; por eso puede referirse el poeta a su padre como aquel de buenos abrigo, / amado por virtuoso / de la gente (Coplas xxv 289-291, 125). Por eso, porque vivió amando y siendo amado, puede morir de igual manera, rodeado de amigos y parientes que lo lloran, y por eso la muerte no tiene poder alguno para derribarlo, sino apenas para invitarlo razonada y razonablemente a seguirla. El poder del maestre, nacido de su amor, es igual de fuerte que el poder de la muerte, y por ello no hay lucha entre ambos, sino diálogo, acuerdo y paz. A su modo, también la muerte es amada por el maestre, acogida en su casa como una amiga más. No hay aquí necesidad de flechas que derriben muros, sino apenas de una mano que llame a una puerta que se abrirá sin resistencia y con confianza.

La casa del maestre expresa por lo tanto, en oposición al castillo de la vanagloria, del falso poder y de la mera exterioridad, el verdadero poder del amor y la identidad real e intimísima de su dueño, fundada precisamente en esa capacidad donativa de sí que se define como amor, y que encuentra su relato apretado, vívido y elocuente en la breve biografía que precede a la llegada de la muerte. Siempre se ha evaluado esta síntesis biográfica como una mera narratio retórica orientada al encomio del personaje homenajeado en el poema; lo es, sin duda, pero no creemos del todo descaminado ver también en ella, trasladada a la voz del poeta, un acto de automemoración, de repaso de su entera vida, por parte del propio personaje. Trataríase casi de una especie de monólogo interior de don Rodrigo que el poeta nos allega mediante un ejercicio sui generis del estilo indirecto libre, sin marcas explícitas de subordinación enunciativa que nos permitan identificarlo inmediatamente como tal, pero cuya contextualización en el momento previo a la muerte le confiere una inequívoca función de recapitulación, evaluación y examen de conciencia asumida por el propio muriente ya de cara a su hora suprema. Es, en cierto modo, la última y máxima afirmación retrospectiva de su identidad personal, de su identidad narrativa -diría Paul Ricoeur-, al momento de presentarse ante Dios para, con ella en la voz y en las manos como fruto meritorio de su vida, rogar y esperar el premio del cielo, según explícitamente ruega en su plegaria de la estrofa 33. La casa viene entonces a representar en el plano de la espacialidad esta misma identidad personal de donación, apertura y amor que la biografía recordada en fugaz pantallazo retrospectivo representa en el plano de la temporalidad. Ya señalaba Bachelard (1965: 38) en sus clásicos trabajos sobre el simbolismo espacial que la casa es el ámbito que «alberga el ensueño [...], protege al soñador [...], permite soñar en paz»:

[...] La casa es uno de los mayores poderes de integración para los pensamientos, los recuerdos y los sueños del hombre. En esa integración, el principio unificador es el ensueño. El pasado, el presente y el porvenir 
dan a la casa diferentes dinamismos [...]. Sin ella, el hombre sería un disperso. Lo sostiene a través de las tormentas del cielo y de las tormentas de la vida. Es cuerpo y alma (Bachelard 1965: 39).

Es justamente esta unificación de pensamientos, recuerdos y sueños, de presente, de pasado, de futuro, lo que convierte a nuestra actividad psíquica en un yo, en un sujeto, en una identidad ${ }^{21}$. La casa expresa esa unidad, unidad que es del todo interior, profundamente íntima, y por ello mismo, nocturna. La casa del maestre recupera así para el poema -y para la dialéctica que la muerte establece con las distintas construcciones arquitectónicas que simbólicamente se le oponen- la vigencia del régimen nocturno que en el castillo puramente vertical y exterior de la estrofa 24 estaba del todo ausente. En tal sentido, la casa de don Rodrigo se hermana con aquel otro castillo, el del poema VIII, que también se definía por su pura y plena nocturnidad, por una fortaleza y una virtud inescalables e imbatibles que procedían, como en este caso, del amor reinante en su interior, amor constitutivo de una identidad cabal, en verdad subsistente a los embates de la vida -poema VIII- o de la muerte - Coplas $-^{22}$.

\section{A MODO DE CONCLUSIÓN}

Según hemos visto, el castillo -y su figura eventualmente isomorfa, la casa- es una imagen compleja que aúna los dos regímenes básicos de la imaginación simbólica: el diurno, por su elevación, y el nocturno, por su intimidad ${ }^{23}$. Ambos regímenes, cada uno a su modo, concurren en la

\footnotetext{
${ }^{21} \mathrm{Y}$ en una conciencia, cabría añadir, abogando, de paso, por la mayor pertinencia de la lectura sentidos humanos conservados frente a sentidos humanos olvidados a propósito de la adiáfora de los versos 470-471, que tanto ha dividido a los editores y a los críticos. Véanse, en favor de olvidados, los trabajos de Beltrán (1991: 158; 2016: 73-92) y Morros (2020: 195-214), y en favor de conservados, los de Conde (2009: 59-84) y González (2019a).

${ }^{22}$ Como nuevo detalle en pro de la lectura sentidos humanos conservados, adviértase que los sentidos solo se pierden en los poemas cuyos castillos son abatidos por sus escaladores, esto es, aquellos donde predomina el régimen diurno o, al menos, no hay un claro dominio del nocturno; así en el poema I: y aunque todos mis sentidos / de sus fines no gozaron (71-72, 5); y así en el VI: luego todos mis sentidos / huyeron a lo más fuerte (9-10, 22); y mis sentidos robaron [vuestros amores] $(31,23)$. En el poema VIII, por el contrario, cuyo castillo es nocturno e interior como la casa de las Coplas, no hay ninguna referencia a una pérdida de los sentidos: en los habitáculos del amor la conciencia y la sensibilidad de las cosas se conserva hasta el final, como hasta el final se conservan su real poder y su invulnerabilidad.

${ }^{23}$ Esta antítesis, que Durand define en términos de arquetipos diurnos y nocturnos, la postula la más moderna teoría de la metáfora conceptual de la lingüística cognitiva oponiendo los esquemas de imagen de la verticalidad y del recipiente. La verticalidad, «que se asocia con la orientación arriba-abajo, puede interpretarse como un camino con orientación vertical. Sin embargo, es necesario resaltar dos aspectos que confieren a este esquema un estatus diferenciador con respecto al de camino y que definen en último término este patrón experiencial: su valor axiológico inherente (si bien este hecho es una tendencia más que una norma, pues es solo prototípicamente que la orientación arriba se relaciona con un valor axiológico positivo y abajo con una carga negativa) y su relación con el modelo cognitivo de control (esto emerge de
} 
definición del sentido más propio de la imagen, el de fortaleza defensiva o protectora, pues el castillo es fuerte y resistente tanto por ser elevado y así inaccesible, cuanto por ser cerrado e íntimo, y así impenetrable. Pero profundizando más y mejor en el análisis, hemos visto también que esta integración y complementariedad de los regímenes no es igualitaria, sino se resuelve a la postre en favor de una mayor determinación del régimen nocturno a la hora de postular el tipo de fortaleza y protección más efectiva, duradera y verdadera. La eficacia de la elevación como elemento protector, pareciera decírsenos, depende de la eficacia de la interioridad como elemento de clausura. Cuanto más íntima y recogida sea la vida del castillo o de la casa, más efectivos serán sus torres o sus altos muros para protegerla. En otros términos: cuanto más y mejor amor reine adentro, más difícil será para los agentes de afuera escalar el arriba. La sumidad se sostiene en la interioridad, la cabeza en el corazón, la extremidad en el centro. $\mathrm{O}$ como ya se dijo más claramente, el poder en el amor.

Dos aspectos importantes deben sentarse con respecto a la equivalencia entre amor y poder, que permiten comprender acabadamente sus alcances. En primer término, que el amor en cuestión se entiende ante todo como deseo, como acto de voluntad. Pero además, que ese amordeseo, por dirigirse a un objeto de suyo inalcanzable o que no permite una posesión plena, no se identifica con el gozo, sino con un dolor que, paradojalmente, puede llegar a dar placer en cuanto sufrimiento consentido y ennoblecedor. Se trata, por una parte, del tipo de padecimiento propio del amor cortés, generado por la insatisfacción en la consumación del deseo erótico, que sin embargo proporciona al amante la satisfacción de la lealtad observada y del servicio debidamente cumplido (Parker 1986: 33, 36), pero se trata también del amor familiar, amical, social, político y religioso del maestre don Rodrigo, que proporciona ciertamente antes trabajos y pesares en su realización como deber -para

nuestra experiencia cotidiana de acuerdo con la cual una posición elevada nos permite controlar entidades que están situadas en un nivel inferior y por tanto nos confiere poder sobre otras entidades)» (Peña Cervel 2012: 78). Adviértase que, en efecto, en el caso del castillo del poema VI la conquista de la sumidad, el acceso al arriba, asegura a la dama escaladora el control y el poder, de donde la valoración positiva de ese arriba en cuanto meta deseable. Con respecto al esquema del recipiente, «está compuesto por los siguientes elementos estructurales: un interior, un exterior y un límite [...]. Según su lógica interna, las entidades han de estar dentro o fuera del recipiente; [...] los límites impiden que las entidades externas afecten a las que se hallan dentro de la región delimitada; si alguna entidad accede al recipiente, esta afectará o será afectada positiva o negativamente por la/s entidad/es situada/s dentro de la región tridimensional» (Peña Cervel 2012: 77). Las características de este esquema se ven claras en el caso del castillo del poema VIII, inexpugnable en razón de su fuerte interior regido por el amor, cuya condición de recipiente protege a las entidades que en él se hallan de todo ataque externo; pero también se observan en el poema I, donde el escalador logra asaltar el castillo, pero resulta al cabo engullido, doblegado por el interior potente de este, que lo asimila a su intimidad amorosa. En síntesis, el esquema del recipiente acaba en ambos casos imponiéndose al de verticalidad, ya sea porque rechaza al escalador, ya sea porque lo absorbe. 
con su rey verdadero, para con sus vasallos, para con sus cofrades de orden, para con su Dios y su fe, para con sus parientes y amigos, según se detalla en el encomio y la biografía de las estrofas 24 a 33- que goces directamente habidos en su posesión, pero que se vive con todo como plenitud y como real felicidad. La postulación de un poder fundamentado en el amor, y de un amor entendido como un servicio sufriente, pero gozosamente asumido, antes que como una posesión de suyo dichosa, es fácilmente discernible a partir de la ideología y la tópica del universo cortés, pero no ha sido debidamente destacada hasta ahora como también presente y operante en el universo semántico de las Coplas; a partir del análisis y la interpretación de las metáforas homologables del castillo asaltado y de la casa visitada que aquí ofrecemos nos hemos apenas asomado a esta clave hermenéutica, que vincula y confiere unidad de sentido y concepción a toda la obra de Manrique, y no solo a la de cuño cortés, pero se trata de un camino apenas incoado que reclama abordajes más completos y sistemáticos ${ }^{24}$.

\section{REFERENCIAS BIBLIOGRÁFICAS}

Alfonso X el Sabio (1848), Código de las Siete Partidas. Madrid: Imprenta de la Publicidad.

Alonso, Dámaso (1958), «Berceo y los topoi», en su De los siglos oscuros al de oro. Madrid: Gredos, pp. 74-85.

Bachelard, Gaston (1965), La poética del espacio. México D. F.: Fondo de Cultura Económica.

BATTESTI-PÉLÉGRIN, Jeanne (1984), «Faire l'amour ou la guerre? À propos de certaines metaphores de Jorge Manrique», Cahiers d'Études Romanes, 10, pp. 7-31.

Beltrán, Vicenç (1991), Coplas que hizo Jorge Manrique a la muerte de su padre. Edición crítica, con un estudio de su transmisión textual. Barcelona: Promoción de Publicaciones Universitarias.

Beltrán, Vicenç (2016), «Los sentidos humanos ¿conservados u olvidados?», Revista de lexicografia, 22, pp. 73-92.

Casas Rigall, Juan (1995), Agudeza y retórica en la poesía amorosa del cancionero. Santiago de Compostela: Universidade de Santiago de Compostela.

Compagno, Filomena (2008), «La lírica amorosa de Jorge Manrique: tópicos y lenguaje», eHumanista, 11, pp. 121-135.

${ }^{24}$ Para corroborar la presencia de esta misma ideología de la correlación causal entre amor, servicio y poder real en una obra narrativa casi contemporánea de Manrique, considérese el vasto ciclo novelesco configurado por el Amadis de Gaula refundido por Garci Rodríguez de Montalvo y las Sergas de Esplandián. Cfr. González 2000 y 2010. 
Conde, Juan Carlos (2009), "Conservados/olvidados: una copla de Manrique y los límites del método neolachmanniano», Incipit, 29, pp. 59-84.

Domínguez, Frank A. (1988), Love and Remembrance. The Poetry of Jorge Manrique. Lexington: The University Press of Kentucky.

DURAND, Gilbert (2004), Las estructuras antropológicas del imaginario. Introducción a la arquetipología general. México: Fondo de Cultura Económica.

Gilman, Stephen (1991), «Tres retratos de la muerte en Jorge Manrique», en VV.AA., El comentario de textos, 4. La poesía medieval. Madrid: Castalia, pp. 305-324.

Gómez Galán, Antonio (1960), «Contribución al estudio de las Coplas de Jorge Manrique», Arbor, 45, pp. 212-227.

GonzÁLEZ, Javier Roberto (2000), «Los límites de la cortesía: amor y poder en el Amadís-Sergas», en Melchora Romanos y Florencia Calvo (eds.), Lecturas críticas de textos hispánicos. Estudios de literatura española del Siglo de Oro. Buenos Aires: Eudeba, II, pp. 69-78.

GoNZÁLEZ, Javier Roberto (2010), «La estructura trifuncional indoeuropea en la contrautopía del Amadís-Sergas», Literatura: teoría, historia, crítica, 12, pp. 39-70.

GoNZÁLEZ, Javier Roberto (2019a), «La adiáfora conservados/olvidados en las Coplas de Jorge Manrique a la luz de la doctrina medieval de los diez sentidos del alma», Incipit, 39, pp. 37-63.

GoNZÁLEZ, Javier Roberto (2019b), «Del homo viator a la muerte huésped en las Coplas de Jorge Manrique», Letras, 80, pp. 8-22.

GoNZÁLEZ, Javier Roberto (2020), «La metaforicidad bio-tanática en las Coplas de Jorge Manrique», Moenia, 26, pp. 123-148.

GuÉNON, René (1988), Símbolos fundamentales de la ciencia sagrada. $3^{\text {a }}$ ed. Buenos Aires: Eudeba.

S. Juan de la Cruz (1993), Poesía. Edición de Domingo Yndurain. Madrid: Cátedra.

D. JuAn Manuel (1975), Libro del cavallero et del escudero, en Cuenca, Luis Alberto de (ed.), Floresta española de varia caballería. Raimundo Lulio, Alfonso X, Don Juan Manuel. Madrid: Editora Nacional.

Llull, Ramón (1985), Libro de la Orden de Caballería. Barcelona: Teorema.

ManRIQue, Jorge (1985), Obras. Edición de Antonio Serrano de Haro. Madrid: Alhambra.

Manrique, Jorge (2003), Poesía. Edición de María Morrás. Madrid: Castalia.

Manrique, Jorge (2013), Poesía. Edición de Vicenç Beltrán. Madrid: Real Academia Española.

Morros, Bienvenido (2020), «Problemas textuales en la poesía de Jorge Manrique», Revista de filología española, 100/1, pp. 195-214. 
PARKer, Alexander A. (1986), La filosofia del amor en la literatura española 1480-1680. Madrid: Cátedra.

PeÑa Cervel, María Sandra (2012), «Los esquemas de imagen», en Iraide Ibarretxe-Antuñano y Javier Valenzuela (dirs.), Lingüística cognitiva. Barcelona: Anthropos, pp. 69-96.

PiÑa PÉREZ, Marucha Claudia (2020), «Amor y guerra en la poesía de Jorge Manrique. Análisis del decir 'Castillo de amor'», Medievalia, 52/2, pp. 83-98.

Salinas, Pedro (1947), Jorge Manrique o tradición y originalidad. Buenos Aires: Sudamericana.

San Pedro, Diego de (1999), Cárcel de Amor. Tractado de amores de Arnalte y Lucenda. Sermón. Edición de José Francisco Ruiz Casanova. $2^{\mathrm{a}}$ ed. Madrid: Cátedra.

Serrano de Haro, Antonio (1966), Personalidad y destino de Jorge Manrique. Madrid: Gredos.

SuÁRez Pallasá, Aquilino (1994), «El simbolismo del fenómeno de la reflexión acústica y luminosa en las Églogas de Virgilio [primera parte]», Letras, 29-30, pp. 67-87.

SuÁrez Pallasá, Aquilino (1995), «El simbolismo del fenómeno de la reflexión acústica y luminosa en las Églogas de Virgilio [segunda parte]», Letras, 31-32, pp. 111-140.

SuÁReZ Pallasá, Aquilino (2006), «Fenomenología de la obra caballeresca y Amadís de Gaula», en Lilia E. Ferrario de Orduna et al., Nuevos estudios sobre literatura caballeresca. Barcelona/Kassel: Reichenberger, pp. 1-10.

ZEPEDA, Jorge (2006), «La muerte como constante alegórica en las Coplas a la muerte de su padre de Jorge Manrique: un análisis retórico», Medievalia, 38, pp. 33-43. 
$\cos$

\title{
LA METÁFora del CASTILlo EN LA POESÍA DE JoRge MaNRiQUe SEGÚN LA ARQUETIPOLOGÍA DE DURAND
}

RESUMEN: La tópica metáfora del castillo y la alegoría desarrollada a partir de ella han sido ocasionalmente estudiadas en la poesía cortés de Jorge Manrique, así como también a propósito de un celebrado pasaje de sus Coplas a la muerte de su padre. Sin embargo, ningún estudio crítico ha procurado integrar en un único y abarcador análisis de la metáfora del castillo tanto las obras amatorias del poeta cuanto sus Coplas. Este artículo se propone intentar tal tarea, estableciendo los rasgos morfológicos y funcionales de la metáfora del castillo de acuerdo con la arquetipología de Durand, según aparece en la poesía cortés de Manrique y en las Coplas, con el objeto de definir algunas constantes de su personalidad artística más allá de los géneros y los moldes retóricos particulares.

Palabras Clave: Metáfora. Castillo. Jorge Manrique. Diurno. Nocturno. Amor. Poder.

\section{Castle Metaphor in Jorge Manrique’s Poetry ACCORDING TO DURAND's ARCHETYPAL THEORY}

\begin{abstract}
The topical castle metaphor and the allegory based on it have been occasionally studied in Jorge Manrique's courtly poetry, as well as in relation to a celebrated passage from his Coplas a la muerte de su padre. However, no critical study has attempt to integrate, in a single and comprehensive analysis of the castle metaphor, the erotic works of the poet as well as the Coplas. This paper is intended to try such a task, by establishing both morphological and functional features of the castle metaphor, according to Durand's archetypal theory, as it appears in Manrique's courtly poetry and in the Coplas, in order to define some constant factors of his artistic identity beyond genres and particular rhetorical patterns.
\end{abstract}

Keywords: Metaphor. Castle. Jorge Manrique. Diurnal. Nocturnal. Love. Power. 